\title{
Penggunaan Model Pembelajaran Concept Sentence guna Meningkatkan Keterampilan Menulis Puisi Kelas IV Sekolah Dasar
}

\section{Syifana Rizky Normaningtyas Putri}

Universitas Sebelas Maret

Syifanarizky28@gmail.com

\section{Article History}

received 30/4/2021

\begin{abstract}
The low learning outcomes of students can be caused by not using innovative learning models. The purpose of the research is to improve the writting skill of poetry by applying the Cooperative Learning Model Concept Sentence in fourth grade of elementary school of 2 Dibal in academic year 2020/2021. The type of this research is classroom action research (CAR), it consist of two cycles. Each cycles consist of four phases, they are planning, action, observation, and reflection. The subjects of this research are teacher and students in fourth grade consist 25 student. The data collecting technique are interview, observasion, documentation and test. The data validity technique are content validity and triangultion methods. The data analysis is interactive analysis model. The precentage of completness in first cycle is $36 \%$ and increase to $92 \%$ in second cycle. The conclution of the research is appliying cooperative learning model concept sentence can improve the writing skill of poetry on the fourth grade of elementary school 2 Dibal in academic year 2020/2021.

Keywords: Cooperative Learning Model Concept Sentence, Writing Skill, Poetry.
\end{abstract}

\begin{abstract}
Abstrak
Penelitian ini bertujuan untuk meningkatkan keterampilan menulis puisi pada peserta didik kelas IV SD Negeri 2 Dibal tahun ajaran 2020/2021 dengan menerapkan model pembelajaran kooperatif concept sentence. Bentuk penelitian ini merupakan penelitian tindakan kelas (PTK) yang berlangsung selama dua siklus. Tiap siklus terdiri dari perencanaan, tindakan, observasi, dan refleksi. Subjek penelitian ini merupakan guru dan peserta didik dengan jumlah 25 peserta didik. Teknik pengumpulan data adalah wawancara, observasi, dokumentasi, dan tes. Teknik validitas data yang digunakan adalah validitas isi dan triangulasi. Teknik analisis data yang digunakan adalah model analisis interaktif Miles dan Huberman. Siklus I ketuntasan klasikal sebesar $36 \%$ dan siklus II meningkat menjadi $92 \%$. Simpulan penelitian ini adalah penggunaan model pembelajaran kooperatif concept sentence dapat meningkatkan keterampilan menulis puisi peserta didik kelas IV SD Negeri 2 Dibal tahun ajaran 2020/2021.
\end{abstract}

Kata kunci: Concept Sentence, Keterampilan Menulis, Puisi. 


\section{PENDAHULUAN}

Pengajaran bahasa memiliki prinsip dan tujuan yaitu peserta didik terampil berbahasa, meliputi terampil menyimak, terampil membaca, terampil berbicara, dan terampil menulis. Keberhasilan peserta didik dalam kegiatan belajar mengajar disekolah banyak ditentukan oleh keterampilan menulis. Oleh karena itu, keterampilan menulis perlu dikembangkan di jenjang Sekolah Dasar. Menulis dan Keterampilan menulis merupakan bentuk manifestasi kompetensi pembelajaran paling akhir berupa penyampaian pesan secara tertulis kepada kepada pihak lain dengan bahasa tulis sebagai medianya. (Dalman, 2015:3 ; Nurgiyantoro 2016: 463).

Keterampilan menulis puisi adalah salah satu keterampilan menulis di Sekolah Dasar dimulai dari kelas rendah hingga kelas tinggi. Keterampilan menulis puisi merupakan salah satu keterampilan menulis yang harus dikuasai oleh peserta didik. Menulis puisi merupakan keterampilan menulis untuk tujuan imajinatif. Dalam pembelajaran menulis puisi di Sekolah Dasar, peserta didik diajarkan untuk mengungkapkan perasaan maupun pikiran menggunakan bahasa dengan mengandung nilai estetika. Puisi merupakan bentuk pengekspresian pemikiran, sikap maupun kehendak yang membangkitkan perasaan, merangsang imajinasi panca indera dalam susunan yang berirama, dan memberi suatu kesan tertentu (Rukayah, 2012:49; Slamet, 2016:14; dan Winarni, 2014:7). Dalam penulisan puisi tidak hanya menggunakan bahasa yang indah, selain itu juga menggunakan bahasa yang ringkas, namun kaya makna. Penulisan puisi tidak berbentuk paragraf, melainkan pengungkapan kata-kata dalam puisi dituangkan dalam bait atau baris-baris. Kosasih (2012: 97) mengatakan bahwa unsur pembangun puisi terdiri atas unsur lahiriah dan unsur batiniah. Unsur lahiriah dalam puisi meliputi diksi, gaya bahasa, kata konkret, daya bayang (imajinasi), dan rima, sedangkan unsur batiniahnya meliputi tema, rasa, nada, dan amanat.

Berdasarkan hasil kegiatan wawancara dan observasi di SDN 2 Dibal dapat ditarik simpulan bahwa kesulitan peserta didik pada mata pelajaran Bahasa Indonesia terutama dalam pembelajaran menulis puisi. Peserta didik kesulitan dalam mengungkapkan pikiran maupun perasaannya dalam bentuk tulisan berupa puisi. Selain itu peserta didik kesulitan dalam merangkai kata-kata indah yang disesuaikan dengan rima maupun iramanya. Kesulitan yang dialami peserta didik disebabkan diantaranya karena: (1) Kurangnya partisipasi peserta didik, seakan-akan peserta didik menjadi pasif dan pembelajaran menjadi tidak menarik atau membosankan, (2) guru kesulitan untuk mengarahkan peserta didik dalam menulis puisi karena pembelajaran dilaksanakan secara daring.

Menerapkan model pembelajaran kooperatif merupakan solusi yang dapat digunakan untuk meningkatkan keterampilan menulis puisi. Pembelajaran kooperatif telah dikembangkan intensif dengan tujuan meningkatkan kerjasama antar peserta didik dan meningkatkan kerjasama melalui aktivitas kelompok (Rukayah, 2012 : 18). Begitu banyak jenis dan ragam model pembelajaran kooperatif, namun pemilihan untuk penggunaannya haruslah sesuai dengan kebutuhan peserta didik. Adapun model pembelajaran yang sesuai untuk menjadi solusi dari permasalahan yang telah dipaparkan di atas adalah model pembelajaran kooperatif Concept Sentence.

Huda (2014:315) menyatakan bahwa concept sentence merupakan pengembangan dari concept attainment. Model pembelajaran kooperatif Concept Sentence lebih menyenangkan dengan adanya kartu bergambar disertai kata kunci sehingga peserta didik tidak mudah bosan. Disisi lain, model ini juga memudahkan penulisan peserta didik karena terdapat kata kunci yang dapat dikembangkan menjadi beberapa kalimat, serta akan mendorong berpikir kreatif peserta didik agar tidak terlalu monoton dalam menulis. Model Concept Sentence merupakan model pembelajaran yang dikembangkan dari cooperative learning. Model pembelajaran kooperatif Concept 
Sentence dimulai dari mengemukakan tujuan, meyajikan materi, membentuk kelompok heterogen, menyediakan kata kunci yang sesuai dengan materi bahan ajar, dan setiap kelompok membuat kalimat/puisi berdasarkan kata kunci yang ada. Berikutnya, peserta didik mempresentasikan hasil belajar didepan kelas secara bergilir (Guruclub dalam Shoimin (2014:37)). Keterampilan menulis puisi pernah diteliti oleh Proborini dengan tujuan meningkatkan keterampilan menulis puisi melalui penerapan model pembelajaran kooperatif tipe Auditory, Intellectually, Repetition (AIR) pada peserta didik kelas IV dengan hasil keterampilan menulis puisi meningkat dengan penerapan model pembelajaran tersebut. Penelitian dengan dengan menggunakan model pembelajaran kooperatif Concept Sentence pernah dilakukan oleh Wahyu Dwi Yuliani (2019) Melalui penelitian yang dilakukan oleh Wahyu Dwi Yuliani penggunaan model pembelajaran Concept Sentence dapat meningkatkan keterampilan menulis narasi pada siswa kelas III SD Negeri Kenonsari tahun ajaran 2018/2019.

Berdasarkan uraian diatas tujuan penelitian ini adalah meningkatkan keterampilan menulis puisi pada peserta didik kelas IV SD melalui penggunaan model pembelajaran kooperatif Concept Sentence. Model pembelajaran kooperatif Concept Sentence memiliki manfaat yaitu membantu peserta didik membantu mengembangkan kalimat dan menjamin partisipasi antaranggota kelompok. Penelitian ini dapat dijadikan referensi bagi peneliti lain terkait upaya meningkatkan keterampilan menyajikan data dalam bentuk diagram.

\section{METODE}

Penelitian ini dilaksanakan di SD Negeri 2 Dibal pada tahun ajaran 2020/ 2021. Penelitian ini berupa penelitian tindakan kelas (PTK) yang dilaksanakan dalam 2 siklus, setiap siklus terdiri dari empat tahap (Arikunto (2014:3) yaitu: 1) perencanaan; 2) pelaksanaan; 3) observasi; dan 4) refleksi. Subjek penelitian ini adalah guru dan peserta didik kelas IV SD Negeri 2 Dibal sejumlah 25 peserta didik. Teknik pengumpulan data adalah wawancara, observasi, dokumentasi, dan tes. Teknik validitas data yang digunakan adalah validitas isi dan triangulasi. Teknik analisis data yang digunakan adalah model analisis interaktif (Miles dan Huberman). Adapun kategorinya adalah sebagai berikut:

Tabel 1. Kategori Keterampilan Menulis Puisi

\begin{tabular}{cc}
\hline Interval & Kategori \\
\hline$\leq 54$ & Kurang Terampil \\
\hline $54-69$ & Cukup Terampil \\
\hline $70-85$ & Terampil \\
\hline $86-100$ & Sangat Terampil \\
\hline
\end{tabular}

Kategori terampil apabila peserta didik memproleh nilai 70 . Adapun jika terdapat $85 \%$ dari peserta didik mendapatkan nilai $\geq 70$, maka penggunaan model pembelajaran koperatif Concept Sentence dapat meningkatkan keterampilan menulis puisi.

\section{HASIL DAN PEMBAHASAN}

Hasil dan pembahasan pada penelitian ini merupakan hasil tindakan yang telah dilakukan selama 2 siklus dengan menerapkan model pembelajaran kooperatif concept sentence. Langkah-langkah dalam pembelajaran kooperatif concept sentence: 1) menyampaikan tujuan pembelajaran, 2) menyajikan materi terkait, 3) membagi peserta didik secara heterogen, 4) memberikan kata kunci disertai gambar, 5) berdiskusi membuat puisi berdasarkan kata kunci yang telah diberikan, 6) diskusi pleno, dan 7) menyimpulkan. Adapun sebelum dilaksanakan penelitian terlebih dahulu melakukan 
observasi kelas dan wawancara kepada peserta didik serta guru, dengan hasil masih banyak peserta didik yang kurang terampil atau tidak terampil dalam menulis puisi.

Hasil penelitian menunjukan adanya peningkatan menulis puisi dari siklus I dan siklus II. Berikut Tabel 2 menjelaskan mengenai kategori keterampilan menulis puisi antarsiklus:

Tabel 2. Perbandingan Kategori Keterampilan Menulis Puisi Antarsiklus

\begin{tabular}{cccccc}
\hline \multirow{2}{*}{ Interval } & \multirow{2}{*}{ kategori } & \multicolumn{2}{c}{ Siklus I } & \multicolumn{2}{c}{ Siklus II } \\
\cline { 3 - 6 } & & $\begin{array}{c}\text { Jumlah } \\
\text { Peserta Didik }\end{array}$ & Persentase & $\begin{array}{c}\text { Jumlah } \\
\text { Peserta Didik }\end{array}$ & Persentase \\
\hline$\leq 54$ & Kurang Terampil & 3 & $12 \%$ & 0 & $0 \%$ \\
\hline $54-69$ & Cukup Terampil & 13 & $52 \%$ & 2 & $8 \%$ \\
\hline $70-85$ & Terampil & 9 & $36 \%$ & 21 & $84 \%$ \\
\hline $86-100$ & Sangat Terampil & 0 & $0 \%$ & 2 & $8 \%$ \\
\hline
\end{tabular}

Tabel 2 menjelaskan mengenai kategori keterampilan menulis puisi pada siklus I dan siklus II. Siklus I terdapat 3 peserta didik dengan persentase $12 \%$ yaitu kategori kurang terampil, 13 peserta didik dengan persentase $52 \%$ termasuk dalam kategori cukup terampil, dan 9 peserta didik dengan persentase $36 \%$ yang telah mencapai KKM 70 dengan kategori terampil. Siklus I di dominasi nilai pada interval 54-69 dengan kategori cukup terampil. Selanjutnya pada tindakan siklus II meningkat, peserta didik dengan kategori kurang terampil tidak ada, kategori cukup terampil berjumlah 2 dengan persentase 8\%, kategori terampil meningkat menjadi 21 peserta didik dengan persentase $84 \%$, dan kategori sangat terampil berjumlah 2 peserta didik dengan persentase $8 \%$. Hal tersebut diperkuat dengan tabel 3 mengenai perbandingan data nilai keterampilan menulis puisi berikut:

Tabel 3. Perbandingan Nilai Keterampilan Menulis Puisi Antarsiklus

\begin{tabular}{lcc}
\hline \multicolumn{1}{c}{ Keterangan } & Siklus I & Siklus II \\
\hline Nilai rata-rata kelas & 65,40 & 77,80 \\
\hline Ketuntasan Klasikal & $36 \%$ & $92 \%$ \\
\hline Nilai Tertinggi & 78,13 & 90,63 \\
\hline Nilai Terendah & 50 & 65,63 \\
\hline
\end{tabular}

Perbandingan nilai keterampilan menulis puisi pada siklus I dan II ditunjukkan Tabel 3. Data yang ditampilkan dalam tabel nampak adanya peningkatan antarpertemuan. Tabel 3 dapat digambarkan dalam gambar grafik 1 berikut:

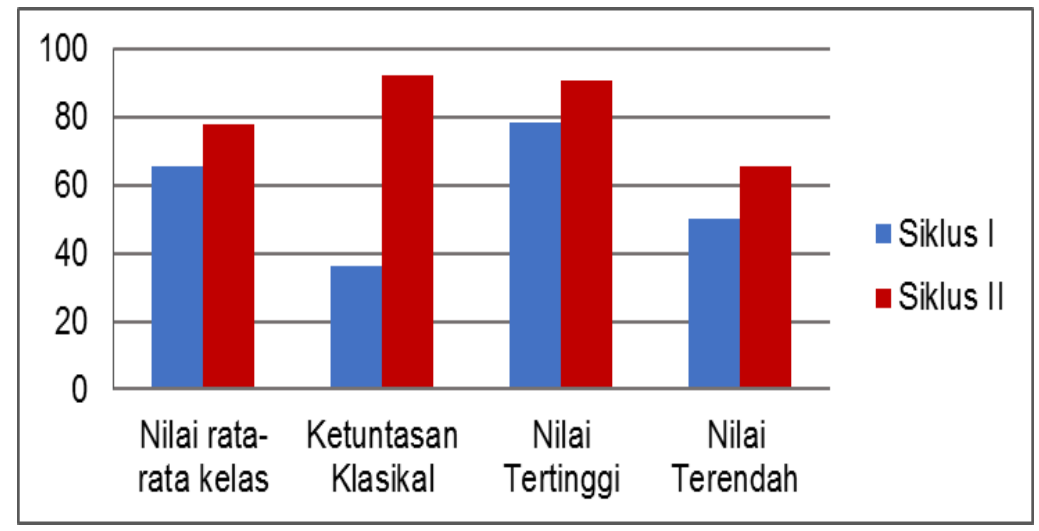

Gambar 1 Grafik Perbandingan Nilai Keterampilan Menulis Puisi Antarsiklus 
Grafik 1 menunjukkan nilai rata-rata kelas pada siklus I mengalami peningkatan pada siklus II sebesar 12,40. Ketuntasan klasikal pada siklus I ke siklus II juga mengalami peningkatan, persentase peningkatan sebesar $56 \%$. Nilai tertinggi dan nilai terendah pada siklus I mengalami peningkatan pada siklus II. Peningkatan nilai tertinggi dari siklus I ke siklus II yaitu dari nilai 78,13 menjadi 90,63 dan peningkatan nilai terendah dari nilai 50 pada siklus I menjadi 65,63 pada siklus II.

Penerapan model pembelajaran kooperatif Concept Sentence dalam pembelajaran pada siklus I dan siklus II memberikan dampak terhadap peningkatan nilai keterampilan menulis puisi pada peserta didik kelas IV SDN 2 Dibal. Hal tersebut dapat diketahui setelah membandingkan hasil pada siklus I dan II. Pelaksanaan pembelajaran pada siklus I dengan menerapkan model pembelajaran kooperatif Concept Sentence masih terdapat beberapa kekurangan yang kemudian diperbaiki di siklus II. Kekurangan pelaksanaan siklus I kemudian dijadikan patokan dalam melaksanakan perbaikan pada siklus II.

Adapun meningkatnya keterampilan menulis puisi pada setiap siklus adalah dampak dari meningkatnya keaktifan peserta didik dan kinerja guru menjadi lebih baik. Berdasarkan data peningkatan aktifitas peserta didik, penggunaan model pembelajaran kooperatif Concept Sentence memberikan dampak sebagai berikut: 1) peserta didik menjadi antusias dan tertarik, serta lebih fokus, 2) peserta didik menjadi berani berpendapat dan secara aktif bertanya maupun menjawab pertanyaan guru, 3) peserta didik menjadi kompak dalam tugas berkelompok. Hal tersebut sejalan dengan kelebihan model pembelajaran Concept Sentence yang dikemukakan oleh Huda (2014) dan penelitian relevan Wahyu Dwi Yuliani (2019) bahwa penggunaan model pembelajaran kooperatif Concept Sentence dapat meningkatkan keterampilan menulis. Adanya keterkaitan tersebut membuktikan penelitian dengan penerapan model pembelajaran kooperatif Concept Sentence guna meningkatkan keterampilan menulis puisi peserta didik kelas IV SD Negeri 2 Dibal Kecamatan Ngemplak Kabupaten Boyolali tahun ajaran 2020/2021 meningkat dan di katakan berhasil telah melebihi indikator kinerja penelitian $85 \%$ serta siklus dihentikan.

\section{SIMPULAN}

Berpijak dari hasil penelitian dan pembahasan dapat ditarik suatu simpulan yaitu penggunaan model pembelajaran kooperatif concept sentence dapat meningkatkan keterampilan menulis puisi peserta didik kelas IV SDN 2 Dibal tahun ajaran 2020/2021. Adapun implikasi pada penelitian ini berupa implikasi teoretis dan praktis. Implikasi teoretis pada penelitian ini yaitu hasil penelitian menunjukkan bahwa model pembelajaran kooperatif Concept Sentence dapat meningkatkan keterampilan menulis puisi peserta didik kelas IV SD Negeri 2 Dibal tahun ajaran 2020/2021 dan implikasi praktisnya yaitu hasil penelitian dengan penerapan model pembelajaran kooperatif Concept Sentence dapat berkontribusi pada peningkatan kinerja guru, keaktifan peserta didik, dan keterampilan menulis puisi peserta didik.

\section{DAFTAR PUSTAKA}

Arikunto, Suhardjono, dan Supardi. 2014. Penelitian Tindakan Kelas. Jakarta: Bumi Aksara.

B. Nurgiyantoro 2016 Penilaian Pembelajaran Bahasa Berbasis Kompetensi (Yogyakarta: BPFE-Yogyakarta)

Dalman. 2015. Keterampilan Menulis. Jakarta: PT. RajaGrafindo Persada.

Huda, Miftahul. 2013. Cooperative Learning Metode, Teknik, Struktur, dan Model Terapan. Yogyakarta: Pustaka Pelajar.

Kosasih, E. 2012. Dasar-dasar Keterampilan Bersastra. Bandung: Yrama Widya. 
Volume 9 Nomor 1 Tahun 2021

Proborini, R.Winarni, and L. Lestari 2018 Improvement Of Poetry Writing Skill Through Auditory, Intellectually, Repetition (Air) Based On Outdoor Study (Classroom Action Research Of Third Grade At Sd Negeri Soropadan No. 108 Surakarta Academic Year 217/2018) SHEs: Conference Series 1 (1) 626-633.

Rukayah. 2012. Pedoman Pelaksanaan Pembelajaran Sastra Anak dengan Pendekatan Kooperatif di Sekolah Dasar. Surakarta: UNS Press.

Shoimin, Aris. 2014. 68 Model Pembelajaran INOVATIF dalam Kurikulum 2013.Yogyakarta: AR-RUZZ MEDIA

Slamet dkk. 2016. Pengkajian Menulis Puisi. Surakarta: UNS Press.

W.D Yuliani, M.Ismail, and H.Mahfud. 2019 Peningkatan Keterampilan Menulis Narasi melalui Model Pembelajaran Kooperatif tipe Concept Sentence Menggunakan Media Gambar Seri Kelas III Sekolah Dasar. Didakt. Dwija Indria vol.7, no 3.

Winarni, Retno. 2014. Kajian Sastra Anak. Yogyakarta: Graha IImu. 